\title{
TAXONOMIC NOTES ON ARISTOLOCHIA DILATATA BROWN FROM INDIA: LECTOTYPIFICATION AND A NEW SYNONYM
}

\author{
Truong Van Do ${ }^{1 *}$, Christoph Neinhuis and Stefan Wanke \\ Technische Universität Dresden, Institut für Botanik, Dresden, Germany \\ Key words: Aristolochia dilatata, Aristolochia gourigangaica, India, Lectotypification, Synonym, \\ Taxonomy
}

\begin{abstract}
Aristolochia gourigangaica Nair is proposed here as a synonym of Aristolochia dilatata Brown. Furthermore, the lectotype of Aristolochia dilatata is designated. Its relationship with Aristolochia punjabensis is also discussed.
\end{abstract}

Aristolochia L. comprises about 500 species representing the largest genus of Aristolochiaceae (Neinhuis et al. 2005). The genus is subdivided into three subgenera: Aristolochia (Schmidt) Ma, Siphisia (Rafinesque) Duchartre, and Pararistolochia (Hutchinson \& Dalziel) Schmidt (González and Stevenson 2002, Neinhuis et al. 2005, Wanke et al. 2006). Aristolochia subgenus Siphisia comprises about 70 species, 50 of which occur in East and South Asia while the remaining 20 species are restricted to Central and North America (Wagner et al. 2012, Do et al. 2014, González et al. 2014). Among the Asian tropics, this subgenus mostly occurs throughout the Himalayan and Indo-Chinese region (including southern China).

In contrast to the well-known studies in respect of Siphisia taxonomy from Thailand (Phuphathanaphong 1987), China (Hwang et al. 2003), Vietnam (Do et al. 2014), nomenclature and relationship of Siphisia species from the Himalayan region is still problematic.

Brown (1911) originally described Aristolochia dilatata from India, a name, however, invalid under Art. 9 of the Melbourne Code (Mcneill et al. 2012), because the holotype was not indicated. The author mentioned a syntype comprising of three gatherings: R. Strachey \& J.E. Winterbottom s.n. (K-000820411), J.E. Winterbottom s.n. (K000820412), and R. Strachey \& J.E. Winterbottom 609 (K-000820410) instead. They were all collected at approximate 2300-2400 m from Kumaon, Uttar Pradesh, India. The first sheet shows both open flowers and mature fruits, the second sheet again flowers and fruits but the flower was not really open, and the third carries the perianth only, while ovary and pedicel are missing. Because diagnostic characters of Aristolochia flowers are more distinctive than those of fruits to differentiate species the specimen $R$. Strachey \& J. E. Winterbottom s.n. (K000820411) is assigned as the lectotype of Aristolochia dilatata here (Fig. 1).

Furthermore, Nair (1969) described Aristolochia gourigangaica from India based on the specimen N.C. Nair 35654 (K001050405) (Fig. 2). However, our thorough investigation of the type specimens revealed that the specimens N.C. Nair 35654 is almost identical to R. Strachey \& J.E. Winterbottom s.n. (K000820411) by a deltoid to deltoid-ovate lamina with a densely grey villous adaxial surface, perianth yellow on the outside with parallel veins, an equally inflated tube and a discoid-subrotundate limb, dark-purple with three indistinct lobes. Aristolochia gourigangaica is insufficiently distinct from A. dilatala to be maintained as separate taxon. Thus, Aristolochia gourigangaica is here considered as a synonym of Aristolochia dilatata.

*Corresponding author: dovantruong_bttn@yahoo.com. ${ }^{1}$ Vietnam National Museum of Nature, Vietnam Academy of Science \& Technology, Vietnam. 
Aristolochia dilatata Brown, Bull. Misc. Inform. Kew 1911: 274 (1911).

Type: INDIA. Uttar Pradesh, Kumaon, elev. 2438 m, R. Strachey \& J.E. Winterbottom s.n. (lecto. K000820411, designated here). - Syntype: INDIA. Uttar Pradesh, Kumaon, valley of Ramgunga, 15 May 1848, J.E. Winterbottom s.n. (K 000820412!); Madhari Pass, elev. 2440 m, R. Strachey \& J.E. Winterbottom 609 (K 000820410 !).

Synonym: Aristolochia gourigangaica Nair, Bull. Bot. Sur. Ind. 10: 332 (1969).-Type: INDIA. Uttar Pradesh, Kumaon: Radgadi Pith-oragarh, Gourigangaica valley, elev. 2800 m, 04 May 1965, N.C. Nair 35654 (holo. K 001050405 !). syn. nov.

Ma (1989) synonymized A. dilatata with A. saccata Wallich. Besides having a different leaf blade, A. saccata has the flowers arranged in cyme on old woody stems and three revolute lobes forming a trumpet-shaped limb. In contrast, the flower of Aristolochia dilatata is solitary or terminal on young branches, limb lobes greatly dilated.

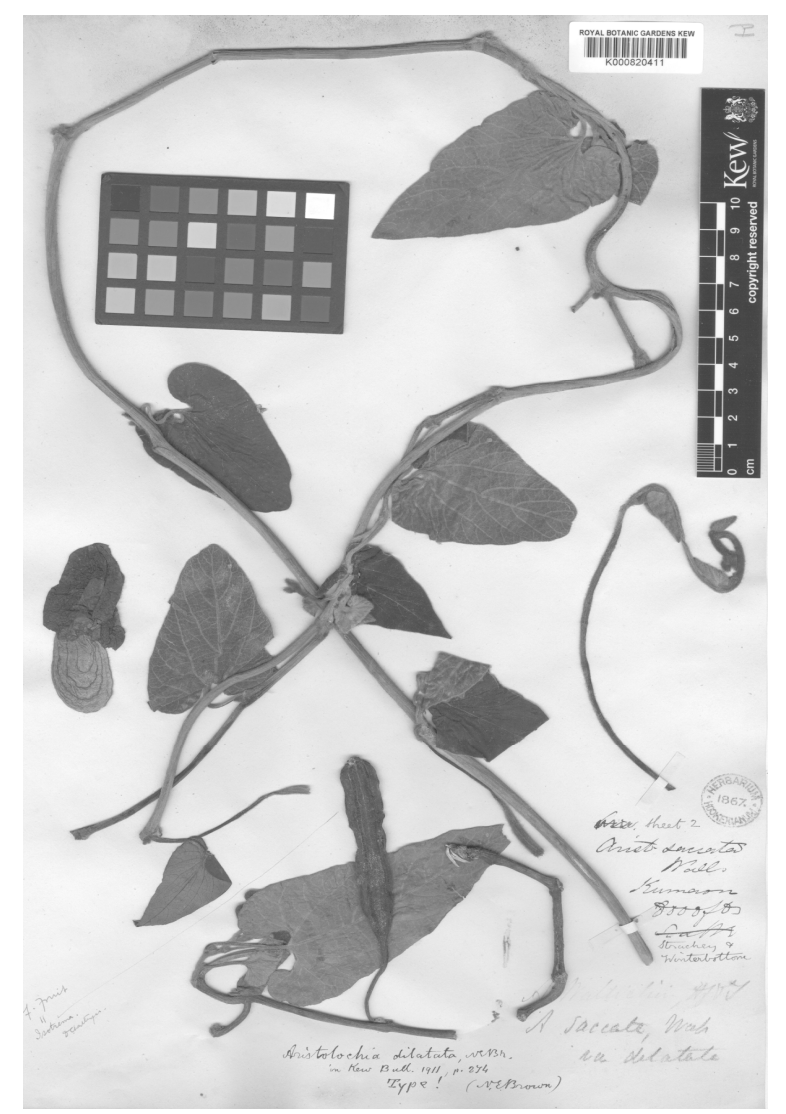

Fig. 1. Lectotype of Aristolochia dilatata (R. Strachey \& J.E. Winterbottom s.n. - K 000820407).

Aristolochia dilatata is most similar to Aristolochia punjabensis Lace in the leaf blade, abaxial leaf surface hairy as well as solitary flower on young branches. However, it is clearly distinguishable from the latter by the diagnostic characters of the perianth, which is glabrescent vs. villous, the upper tube is inflated vs. strongly constricted and the limb lobes are indistinctly 3-lobed vs. distinctly broadly ovate 3-lobed. 


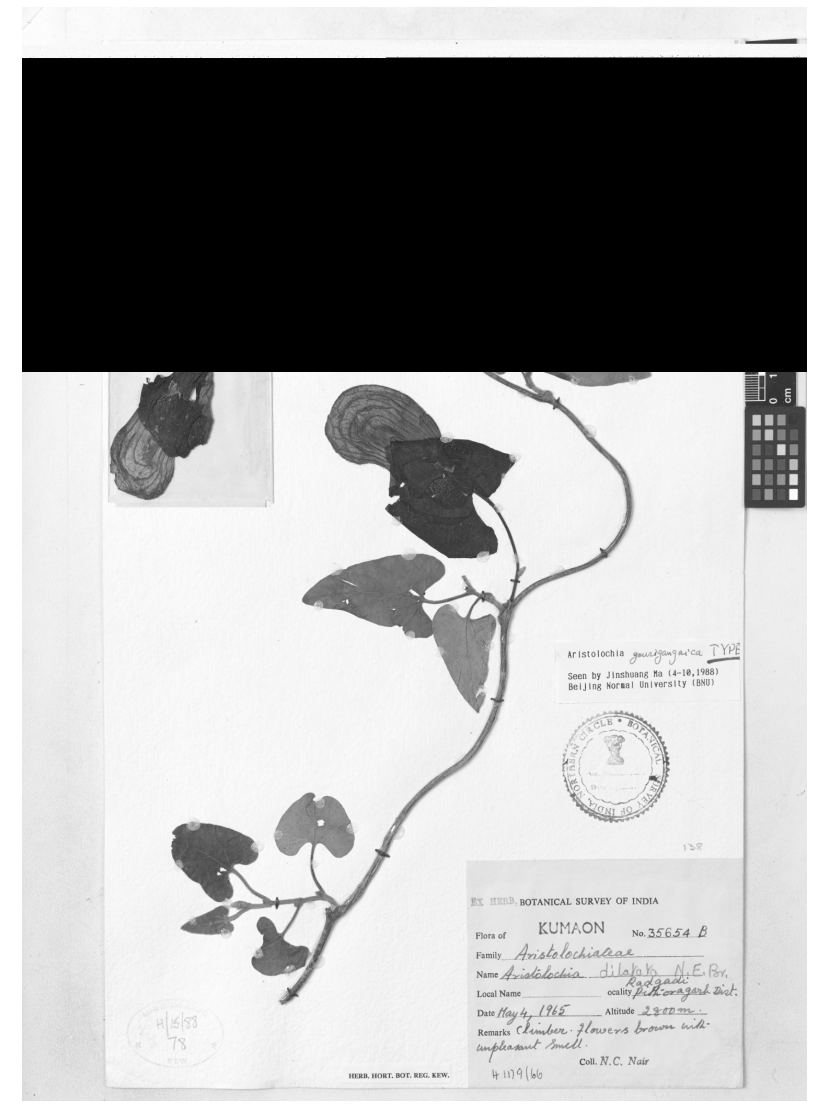

Fig. 2. The type of Aristolochia gourigangaica (N.C. Nair 35654 - K 001050405)

\section{Acknowledgements}

The authors are grateful to the curators and staff of $\mathrm{K}, \mathrm{P}$ for making material available to us as well as loaning specimens or providing online access to specimens. The first author would like to thank Erasmus Mundus program for financial support to enrol his Ph.D. at the TU Dresden, Germany.

\section{References}

Do TV, Nghiem TD, Wanke S and Neinhuis C 2014. Aristolochia quangbinhensis (Aristolochiaceae), a new species from Central Vietnam. Phytokeys 33: 51-59.

González F and Stevenson DW 2002. A phylogenetic analysis of the subfamily Aristolochioideae (Aristolochiaceae). Rev. Acad. Colomb. Cienc. 26: 25-60.

González F, Wagner ST, Salomo K, Samain MS, Isnard S, Rowe NK, Neinhuis C and Wanke S 2014. Present trans-Pacific disjunct distribution of Aristolochia subgenus Isotrema (Aristolochiaceae) was shaped by dispersal, vicariance and extinction. J. Biogeogr. 41: 380-391.

Hwang SM, Kelly LM and Gilbert MG 2003. Aristolochiaceae. In: Flora of China. Vol. 5, Z.Y. Wu and H.R. Peter (eds.). pp. 246-269. Beijing: Science Press and St. Louis: Missouri Botanical Garden Press.

Ma JS 1989. A revision of Aristolochia Linn. from E. and S. Asia. Acta Phytotax. Sin. 27(5): 321-364. 
McNeill J, Barrie FR, Buck WR, Demoulin V, Greuter W, Hawksworth DL, Herendeen PS, Knapp S, Marhold K, Prado J, Prud'Homme Van Reine WF, Smith GF and Wiersema JH 2012. International code of nomenclature for algae, fungi, and plants (Melbourne Code), adopted by the eighteenth international Botanical Congress Melbourne, Australia, July 2011 (Regnum Vegetabile, 154). A.R.G. Gantner Verlag, Ruggell, 208 pp.

Nair NC 1969. Aristolochia gourigangaica. Bull. Bot. Surv. India 10: 332.

Neinhuis C, Wanke S, Hilu KW, Muller K and Borsch T 2005. Phylogeny of Aristolochiaceae based on parsimony, likelihood, and Bayesian analyses of trnL-trnF sequences. Plant Syst. Evol. 250: 7-26.

Ohi-Toma T, Sugawara T, Murata H, Wanke S, Neinhuis C and Murata J 2006. Molecular phylogeny of Aristolochia sensu lato (Aristolochiaceae) based on sequences of $r b c \mathrm{~L}, m a t \mathrm{~K}$, and phy $\mathrm{A}$ genes, with special reference to differentiation of chromosome numbers. Syst. Bot. 31: 481-492.

Phuphathanaphong L 1987. Aristolochiaceae. Flora of Thailand 5: 1-31.

Royal Botanic Gardens, Kew 1911. Plantarum novarum in herbario horti regii conservatarum. Kew Bull. 1911: 273-274. London.

Wagner ST, Isnard S, Rowe NP, Samain MS, C Neinhuis and Wanke S 2012. Escaping the lianoid habit: evolution of shrub-like growth forms in Aristolochia subgenus Isotrema (Aristolochiaceae). Am. J. Bot. 99(10): 1609-1629.

Wanke S, González F and Neinhuis C 2006. Systematics of pipevines-combining morphological and fastevolving molecular characters to investigate the relationships within subfamily Aristolochioideae (Aristolochiaceae). Int. J. Plant Sci. 167(6): 1215-1227.

(Manuscript received 8 March, 2015; revised on 30 March, 2015) 